\title{
sciendo
}

\section{COOPERATIVE FINANCING AND THE GROWTH OF CATFISH AQUACULTURE VALUE CHAIN IN NIGERIA}

Theophilus Miebi Gbigbi, Felix Odemero Achoja*

Department of Agricultural Economics and Extension, Delta State University Asaba Campus, PMB 95074 Asaba, Nigeria

*Corresponding Author, Email: achojafelix@gmail.com

\section{ARTICLE INFO}

Received: 28 April 2019

Accepted: 9 October 2019

\section{ABSTRACT}

Cooperative-based growth model for agricultural enterprises is gradually gaining popularity in application. This study examined the effect of cooperative financial intervention on the growth of catfish aquaculture value chain in Nigeria. Primary data collected, with well-structured questionnaire from 120 participants in aquaculture value chain, were analyzed with descriptive statistical tools, cost and return function and 4-point likert-type scale. The result shows that $32.3 \%$ and $27.3 \%$ of processors and input suppliers accessed $\mathrm{A} 320,000$ and $\mathrm{A} 270,000$, respectively. Only $18.2 \%$ of producers accessed $A 180,000$. The result indicates that there are more catfish producers than any other operators in the value chain. There is interdependence between catfish producers and input suppliers, processors and marketers in the value chain. Furthermore, catfish processors and inputs suppliers accessed more cooperative loan because their activities were capital intensive. The relatively high amount of cooperative fund accessed by these groups translated high growth rate of $55 \%$ and $53 \%$, respectively. The major constraints to the growth of catfish value chain were inadequate credit access and high expenditure on inputs. Operators in the catfish aquaculture value chain should be encouraged to attend workshops on management techniques to improve the efficiency of their businesses.
Keywords:

Farmers

Cooperative society

Aquaculture

Growth

Profitability
Gbigbi, T. M., Achoja, F. O. (2019): Cooperative financing and the growth of catfish aquaculture value chain in Nigeria. Croatian Journal of Fisheries, 77, 263-270. DOI: 10.2478/cjf-2019-0020. 


\section{INTRODUCTION}

Catfish aquaculture involves the practice of catfish farming in a confined body of water. Globally speaking, catfish aquaculture has been growing steadily in food production subsector at an annual rate of $8.9 \%$ (World Fish Center, 2010). Catfish aquaculture value chain involves various inter-connected and interdependent economic agents that add value to catfish product line such as input suppliers who produce fish feeds, sell feeds fingerlings and chemicals, catfish producers, processors as well as marketers of processed catfish both at whole sale and retail levels. Due to the need for aquaculture in Nigeria to satisfy the increasing demand for catfish, its growth of the industry has become a topical issue to the Nigerian Government during the last decade (Adeogun, 2012). With a demand estimate of 1.4 million tons, Nigeria is considered to be the largest consumer of fish and fish products in the African region. There is an annual demand deficit of approximately 0.7 million metric tons with imports covering the short fall at a cost of approximately 0.5 billion dollars per year (Kudi et al., 2008).

Table 1 shows an estimated steady growth in catfish production (MT) and job creation in catfish value chain in Nigeria (2004 - 2012). This was prompted by the presidential initiative on fisheries and aquaculture growth with strategic financing intervention options in 2003. Cooperative financial intervention was designed to empower catfish aquaculture value chain actors (input suppliers, producers, processors and marketers). The catfish aquaculture industry is therefore connected to functional value chain financing through cooperative approach as shown in conceptual framework in Fig. 1.
Cooperative loan scheme through which funds are made available to catfish farmers at a lower interest rate has been recommended for catfish feed producer, farmers, processors and marketers.

Therefore, the government encouraged cooperative society creation as a strategy to foster collective action aimed at increasing the productivity and efficiency of smallholder fish farmers.

Cooperative is an independent group of people united together to meet their common economic, social needs and goals through a business that is collectively owned and controlled democratically (ICA, 2005; Gábor, 2005). Cooperative societies have been reported to accelerate progress in aquaculture growth over the years (ICA, 2005; Gábor, 2005). Increase in output and income levels are measures of effectiveness of mobilization of savings and loan services of cooperative (financial capital) for catfish aquaculture value chain growth (Sharma et al., 2005; Alufohai and Okorosobo, 2013). Every stage of catfish aquaculture value chain requires cooperative financing (Effiong et al., 2012; Ibitoye 2012). Fish farmers joined a cooperative to meet their pressing financing needs to acquire relevant inputs. The growing concern of catfish aquaculture valuable contribution to economic growth has steered up various strands of research works (Durosh, 2008; Agbo (2009). Cooperative societies engaged in financial intervention for catfish production, processing, marketing and distribution activities (Hartley, 2003). Nweke et al. (2005) reported that cooperative societies intervene through direct agricultural input procurement such as chemicals, equipment, feeds, fingerlings and education of fish farmers on modern farming and management techniques. Few studies had examined the

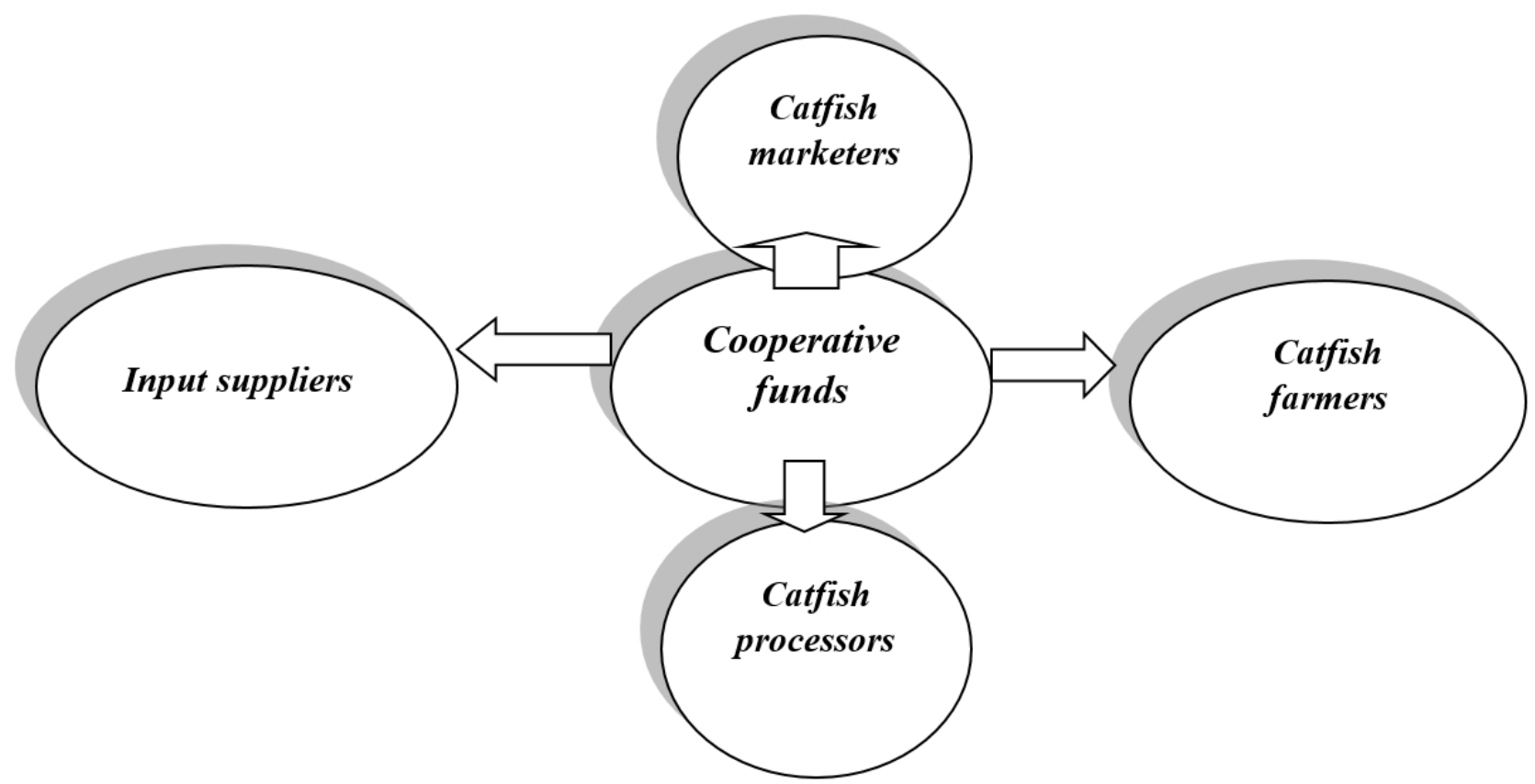

Fig 1. Cooperative funds distribution among value chain operators 
Table 1. An estimated steady growth in catfish production (MT) and job creation in catfish value chain in Nigeria (2004 - 2012)

\begin{tabular}{lcccccccccc}
\hline \hline Species & $\mathbf{2 0 0 4}$ & $\mathbf{2 0 0 5}$ & $\mathbf{2 0 0 6}$ & $\mathbf{2 0 0 7}$ & $\mathbf{2 0 0 8}$ & $\mathbf{2 0 0 9}$ & $\mathbf{2 0 1 0}$ & $\mathbf{2 0 1 1}$ & $\mathbf{2 0 1 2}$ \\
\hline Clarias gariepinus & 35160 & 45084 & 67662 & 68100 & 115000 & 137516 & 180482 & 199015 & 228508 \\
$\begin{array}{l}\text { Clarias hybrid } \\
\text { Heterobrachus sp }\end{array}$ & 703 & 902 & 1353 & 1362 & 2300 & 9168 & 12032 & 13268 & 15234 \\
Total & 2637 & 3381 & 5075 & 5108 & 8625 & 6112 & 8021 & 8845 & 10156 \\
Total job creation: production \& marketing & 38500 & 49367 & 74090 & 74570 & 125925 & 152796 & 200535 & 221128 & 253898 \\
\hline \hline
\end{tabular}

growth response of fisheries sector to external financing through Nigerian Agricultural Cooperative loan (Olaoye et al., 2012).

Using income growth as a proxy for development and productivity of fish farms, they found that the beneficiaries' income level increased substantially over time after receiving cooperative loans. They recommended a scaling-up of the fisheries sector's cooperative funding to boost further growth. The major constraints hampering the growth of the value chain of aquaculture (shrimp), as stated by Achoja (2019), are high feeding costs, insufficient finance and poor marketing network. Agricultural cooperatives support about $71 \%$ of fishery production in the Republic of Korea and $40 \%$ in Brazil (ICA, 2007). But in Nigeria, as it stands, studies on the effect of cooperative financial intervention on the growth of catfish aquaculture are scarce. Consequently, the frontier of understanding needed for relevant policy formulation ought to be extended. This is information gap that the present study examined and filled. The broad objective of this study was to examine how the growth of catfish aquaculture value chain has responded to cooperative financial intervention in Delta State, Nigeria. The specific objectives of the study were to:

i) identify the operators in catfish aquaculture value chain;

ii) examine the operations of catfish aquaculture value chain;

iii) determine the amount of cooperative funding accessed by aquaculture value chain operators in the study area;

iv) assess the rate of catfish aquaculture value chain growth;

v) estimate the profitability of catfish aquaculture value chain operators;

vi) identify the constraints militating against catfish aquaculture value chain growth.

\section{MATERIALS AND METHODS}

\section{Description of study area and sampling proce- dure}

Delta State, Nigeria was affected by this report. One local administration area from each of the three agricultural zones was randomly selected. From the Ministry of Commerce and Industry's list of 3 Local Government Areas, 5 cooperative fish farmers' societies were randomly selected, each of which comprised 15 cooperative fishfarmers' societies in total. Eight cooperators are randomly selected out of fifteen cooperative fish farmers' societies selected, with a total of 120 respondents being randomly selected.

\section{Data analysis techniques}

Descriptive statistics and inferential statistics have been used to analyze data. The increase in the value of income of the value chain operators was used as a proxy for growth in the catfish value chain by the operators both before and after access to a cooperative loan.

\section{Model specification}

Cooperative members have achieved the constraints to aquaculture development on a scale of 4 levels. It uses a normal measuring standard. The answers to different limitations were calculated so that the highest ranking 4 was given for the reply showing the core extreme constraints. The answers have been divided into four points, which are shown below:
a serious problem $=4$;
a moderate problem $=3$;
a minor problem $=2$;
no problem $=1$.

This approach for evaluating constraints is useful since it distinguishes the less serious and important constraints. 


\section{RESULTS AND DISCUSSION}

\section{Description of the operations of catfish aquacul- ture value chain in the study area}

The input suppliers occupy the beginning of the value chain. They supply relevant inputs such as fingerlings, juveniles, feeds, drugs and chemicals to the producers. The producers, on the other hand, produce and sell marketable catfish to the processors. The processor processes and sells to catfish marketers. Processing after harvesting bulk (about 12.5\%) of the catfish is sold live to market mammies (major distributors) at the farm gate, transported to market where they are purchased by bukas (local eateries) and individuals. Others buy to process by means of smoking and drying, using wood or charcoal. The catfish marketers are categorized into wholesalers and retailers. The wholesalers buy in bulk and sell in bulk to the retailers while the retailers sell in small units to the final catfish consumers. Catfish marketing in the value chain involves a wholesale buyer who could get to farm gate to buy the fresh catfish. They sometimes sell to small scale retailers who further sell to the retailers. Some individual buyers and retailers could buy fresh catfish at the farm gate.

Value Addition through smoking, drying and freezing methods are common in catfish value chain. Improved smoking and drying methods are often recommended to attain global standards.

The flow chart below depicts the aquaculture value chain.

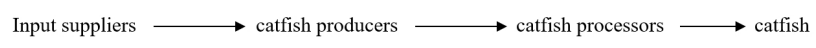

marketers $\longrightarrow$ final catfish consumers

The amount of cooperative financial intervention accessed by aquaculture value chain operators

Table 2 shows the distribution of cooperative credit accessed by various categories of catfish aquaculture value chain operators. The result showed that catfish processors accessed the highest amount of cooperative credit ( $\mathrm{A} 320000$ ) ( $\mathrm{N}=$ Nigerian naira). This takes $32.3 \%$ of the total financial intervention. Furthermore, the findings showed that input suppliers accessed N270 000 indicating $27.3 \%$ of total amount disbursed by cooperative society to catfish value chain operators in the study area. Catfish marketers accessed $\mathrm{N} 220000$ (22.2\%), while catfish producers accessed a mean amount of $\mathrm{N} 180000$ (18.2\%). These results indicate that catfish producers accessed the least amount of cooperative loan disbursed in the study area within the period under review. The consequence is that access to cooperative loans could stimulate business growth. As a result, Akerele and Adekunmbi (2018) have previously found that cooperative credit companies are highly productive and successful in helping members achieve their productive objectives and improve their standard of living in the Ogun State of Nigeria.
Table 2. Distribution credit accessed by catfish aquaculture value chain operators

\begin{tabular}{lllc}
\hline \hline S/N & Operators & $\begin{array}{l}\text { Amount of cooperative } \\
\text { loan accessed }\end{array}$ & $\%$ \\
\hline 1. & Input Suppliers & 270,000 & 27.7 \\
2. & Producers & 180,000 & 18.2 \\
3. & Processors & 320,000 & 32.3 \\
4. & Marketers & 220,000 & 22.2 \\
& Total & 990,000 & 100 \\
\hline \hline
\end{tabular}

Income distribution of catfish value chain operators

Majority (46.67\%) of them earned less than $\mathrm{N} 100,000$. About (35.83\%) had an income of $\mathrm{N100,000-N200,000}$ while only $17.50 \%$ earned income above $\$ 200,000$ The mean annual income of the cooperative farmers was $\mathrm{A}$ $140,073.30$.

Table 3. Income level of catfish value chain operators

\begin{tabular}{llll}
\hline \hline Variable & Frequency & Percentage & Mean/mode \\
\hline$<\uparrow 100,000$ & 56 & 46.67 & \\
$N 100,000-N 200,000$ & 43 & 35.83 & N140, 073.00 \\
$>\Uparrow 200,000$ & 21 & 17.50 & \\
\hline \hline
\end{tabular}

\section{Growth rate of catfish aquaculture value chain activities}

The result showed that the mean income of the input suppliers before acquiring cooperative loan was $\mathrm{A} 72,000$, but after accessing the cooperative loan the income increased to $\$ 110,000$ with a $53 \%$ positive growth rate. Similarly, the mean income of catfish producers before obtaining cooperative loan was $\$ 114,000$ and after benefiting from cooperative loan the income level rose to $\mathrm{N130,000}$ with a $14 \%$ positive growth rate. It is also revealed that the mean income of catfish processors before accessing cooperative loan was $\$ 80,000$, but after acquiring the loan the income level increased to A124,000 with $55 \%$ positive growth rates. The income level of catfish marketers before accessing cooperative loan was $\$ 156,000$ and after obtaining cooperative loan the income was increased to $\$ 184,0000$ with an increase of $18 \%$ positive growth rate. The result further showed that the mean growth rate for the entire catfish value chain operators was $35 \%$. This means that cooperative funding is an important driver of the growth of catfish value chain. The implication of this finding is that any 
Table 4. Growth rate of catfish aquaculture value chain activities

\begin{tabular}{|c|c|c|c|c|c|}
\hline S/No & $\begin{array}{l}\text { Cat fish value chain } \\
\text { operators }\end{array}$ & $\begin{array}{l}\text { Income before cooperative } \\
\text { financial intervention }\end{array}$ & $\begin{array}{l}\text { Income after coop-erative } \\
\text { financial intervention }\end{array}$ & \% Growth Rate & $\begin{array}{c}\text { Avg. } \\
\text { Growth Rate }\end{array}$ \\
\hline 1. & Input suppliers & N72,000 & $\mathrm{N} 110,000$ & $53 \%$ & \\
\hline 2. & Cat fish produc-ers & N114,000 & N130,000 & $14 \%$ & \\
\hline 3. & Cat fish proces-sors & $\mathrm{A} 80,000$ & N124,000 & $55 \%$ & $35 \%$ \\
\hline \multirow[t]{2}{*}{4.} & Cat fish market-ers & $\mathrm{A} 156,000$ & N184,000 & $18 \%$ & \\
\hline & Total & A422,000 & $\mathrm{A} 5448,000$ & & \\
\hline
\end{tabular}

development policy and programme on the growth of catfish aquaculture value chain must involve cooperative financial intervention in Nigeria.

Furthermore, catfish aquaculture value chain operators should belong to cooperative society so as to drive the growth of aquaculture sub-sector in Nigeria. This result supports the earlier report of Gbigbi et al. (2019) who reported that cooperative funding can enhance the development of aquaculture.

\section{Distribution of catfish value chain operators}

The distribution of credit value chain operators is presented in Fig. 2. The result shows that catfish producers (farmers) dominated the value chain (50\%). This was closely followed by catfish marketers (21\%). Further result showed that catfish input suppliers were up to $17 \%$ of the total number of operators in the value chain. However, $12 \%$ of the value chain operators were processors of catfish.

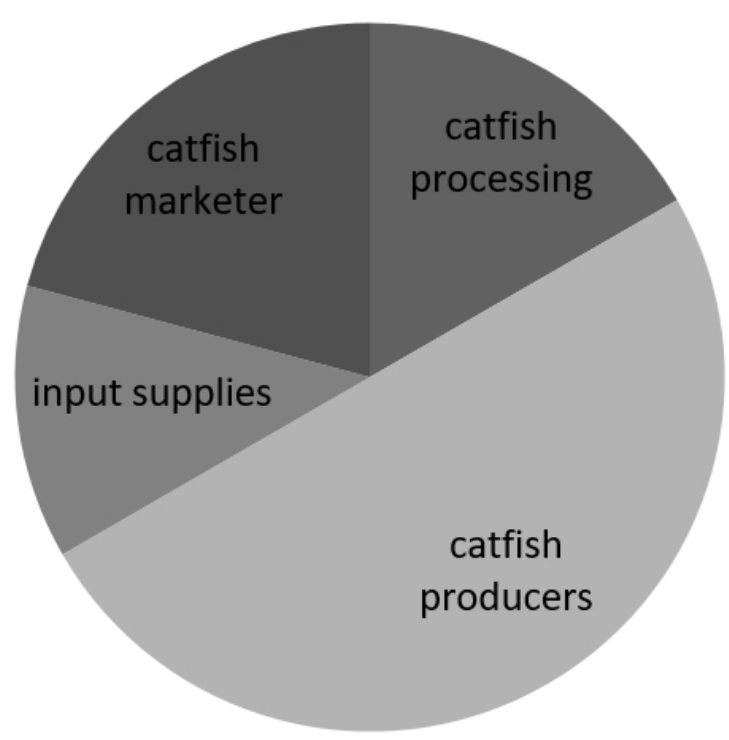

Fig 2. Distribution of catfish value chain operators
The implications of this finding are that (i) more people in the study area were interested in catfish production activities; (ii) catfish marketers are also more in number possibly because of the lucrative nature of the business.

\section{Profitability of catfish aquaculture value chain operators}

Table 5 shows the gross margin and profitability ratio of catfish aquaculture value chain operators. The value chain operators made profits from catfish with a gross margin

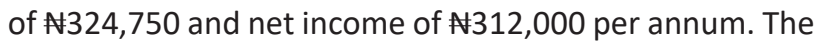
BCR of 1.70 is greater than one. Judging from investment decision criteria, this implies catfish aquaculture is profitable. The ROI was found to be 0.70 , which shows that for every naira invested, 70k was realized. The cost structure reveals that $16.14 \%$ of the total cost generated is to buy fingerlings, and $22.90 \%$ is to pay for labor salaries. The feeding costs measured 53.52 percent, the biggest cost. Prices for medications, pesticide prices, transport costs and fixed input costs accounted for $2.01 \%, 1.25 \%$, $1.34 \%$ and $2.84 \%$, respectively.

\section{Constraints to catfish aquaculture value chain growth}

Five items were listed on a four-point likert-type scale to estimate the relevant variables that were posed by cooperative farmers as constraints to aquaculture growth as shown in Table 6.

Inadequate access to the credit (mean=3.41), high input costs (mean=3.28), management inefficiency (mean=3.07), inconsistent policy (mean=2.82) and poaching (mean=2.66) are significant limitations in aquaculture production, all having mean values that were higher than the cut-off mark of 2.50, according to the Catfish aquaculture value chain. This would discourage aquaculture involvement. 
Table 5. Cost and return of aquaculture value chain of operators

\begin{tabular}{|c|c|c|}
\hline Production parameter & 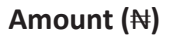 & Percentage \\
\hline Total revenue & 760,400 & \\
\hline \multicolumn{3}{|l|}{ Variable cost } \\
\hline Cost of fingerlings & 72,350 & 16.14 \\
\hline Cost of feeding & 240,000 & 53.52 \\
\hline Cost medication & 9,000 & 2.01 \\
\hline Cost of fertilizer & 5,600 & 1.25 \\
\hline Cost of labour & 102,700 & 22.90 \\
\hline Cost of transportation & 6,000 & 1.34 \\
\hline Total variable cost (TVC) & 435,650 & 97.1 \\
\hline Gross margin & 324,750 & \\
\hline Total fixed cost & 12,750 & 2.84 \\
\hline Total cost & 448,400 & \\
\hline Net income & 312,000 & \\
\hline BCR & 1.70 & \\
\hline ROI & 0.70 & \\
\hline
\end{tabular}

Table 6. Constraints of catfish aquaculture value chain growth

\begin{tabular}{|c|c|c|c|c|c|c|}
\hline Constraints & $\mathrm{SP}(4)$ & $\mathrm{MP}(3)$ & $\mathrm{MIP}(2)$ & $N P(1)$ & Score & Mean \\
\hline High expenditure on inputs & $70(280)$ & $28(84)$ & $7(14)$ & $15(15)$ & 393 & 3.28 \\
\hline Unstable policy & $17(68)$ & $68(204)$ & $31(62)$ & $4(4)$ & 338 & 2.82 \\
\hline Poaching & $29(116)$ & $27(81)$ & $58(116)$ & $6(6)$ & 319 & 2.66 \\
\hline Inadequate credit access & $74(296)$ & $28(84)$ & $11(22)$ & $7(7)$ & 409 & 3.41 \\
\hline Management inefficiency & $40(160)$ & $60(180)$ & $8(16)$ & $12(12)$ & 368 & 3.07 \\
\hline
\end{tabular}

(Source: Survey data, 2018) Serious problem $(S P)=4$, Moderate problem (MP) = 3, Minor problem (MIP) $=2$ and Not at all a problem (NP) $=1$ with a cut-off score of 2.50

\section{CONCLUSION}

This study investigated the effect of cooperative financial intervention on the growth of catfish aquaculture value chain with evidence from Nigeria. There is sufficient evidence to conclude that there are more catfish producers than any other operators in the value chain.
There is interdependence between catfish producers and input suppliers, processors and marketers in the value chain. Furthermore, catfish processors and input suppliers accessed more cooperative loan because their activities are capital intensive. The relatively high amount of cooperative fund accessed by these groups translated a high growth rate of $55 \%$ and $53 \%$, respectively. The 
major constraints to the growth of catfish value chain were inadequate credit access and high expenditure on inputs. Since all the value chain activities recorded an average of $35 \%$ growth rate, it is expected that overall growth of catfish industry will depend on cooperative financial intervention in Nigeria. More catfish farmers should be encouraged to belong to cooperative society. Summarized recommendations are: Operators in the catfish aquaculture value chain should be encouraged to attend workshops on management techniques to improve the efficiency of their businesses. Catfish inputs should be subsidized by the government.

\section{ACKNOWLEDGMENTS}

Our profound appreciation goes to the reviewers whose constructive and objective criticisms contributed to the successful conclusion of this research work.

\section{SAŽETAK}

KOORPORATIVNO FINANCIRANJE I RAST LANCA VRIJEDNOSTI AKVAKULTURE SOMA U NIGERIJI

Model rasta poljoprivrednih tvrtki temeljen na korporativnoj suradnji postepeno dobiva na popularnosti u primjeni. Ova studija ispitala je učinak financijske intervencije na rast lanca vrijednosti akvakulture somovski vrsta u Nigeriji. Primarni podaci prikupljeni su strukturiranim upitnikom od 120 sudionika u lancu vrijednosti akvakulture te su analizirani opisnim statističkim alatima, funkcijom troškova i povratka te 4-bodnom likert skalom. Rezultat pokazuje da je 32,3\% i $27,3 \%$ prerađivača i dobavljača ulaznih materijala dobavilo 320.000 odnosno 270.000 ( $\#=$ nigerijska naira). Samo $18,2 \%$ proizvođača zaradilo je $180.000 \mathrm{~N}$. Rezultat ukazuje na postojanje više proizvođača nego bilo kojeg drugog subjekta u lancu vrijednosti akvakulture soma. Postoji međuovisnost između proizvođača i ulaznih dobavljača te prerađivača i trgovaca u lancu vrijednosti akvakulture soma. Nadalje, prerađivači i dobavljači ulaznih materijala vezanih za proizvodnju soma pristupili su višim iznosima zajma za suradnju zbog kapitalno intenzivne aktivnosti. Ove skupine lanca vrijednosti akvakulture soma pristupile su relativno visokim iznosima kooperativnog fonda što se preslikalo i na njihov visok gospodarski rast od $55 \%$, odnosno 53\%. Glavna ograničenja u rastu lanca vrijednosti akvakulture soma bila su nedovoljan pristup kreditima i visoki izdaci ulaznih sredstava. Operatorima u vrijednosnom lancu akvakulture soma bi trebalo osigurati pohađanje radionica o tehnikama upravljanja kako bi poboljšali učinkovitost svog poslovanja.

Ključne riječi: poljoprivrednici, zadružno društvo, akvakultura, rast, profitabilnost

\section{REFERENCES}

Achoja, F.O. (2019): Analysis of profitability of shrimp value chain in Delta State, Nigeria. Ege Journal of Fisheries and Aquatic Sciences, 36, 2, 125-133.

Adeogun, O. A., Alimi, T., Adeyemo, R. (2012): Status, cost and profitability of aquaculture enterprises in Nigeria: implications for food security. International Journal of Agricultural Sciences 2, 1, 59-66.

Agbo, F. U. (2009): Farmers perception of cooperative societies in Enugu State, Nigeria. Agroscience Journal of Tropical Agriculture, Food, Environment and Extension 8, 3, 169-174.

Akerele, E. O., Adekunmbi, S. A. (2018): Impacts of Cooperative Thrift and Credit Facilities on Members' Business Output in Ogun State, Nigeria. Sustainable Agriculture Research 7, 3, 28-38.

Alufohai, G. O., Okorosobo, T. J. (2013): An assessment of beneficiaries' satisfaction of the management of loan contract components by farmer cooperative societies in Edo State, Nigeria. International Journal of Agricultural Management and Growth 3, 1, 17-21.

Anetekhai, M. A. (2017): Catfish Aquaculture Industry Assessment in Nigeria, A Technical Report.

Durosh, P. (2008): Economics of root and tuber crops in Africa, RCMP research monograph No 1. International of Tropical Agriculture (IITA) Ibadan, 17-20.

Effiong, E. O., Ayanam, B. M., Umoh, G. S. (2012): Analysis of performance of cooperative cassava farmers in Uyo local government area of Akwa Ibom State, Nigeria. Nigerian Journal of Agriculture, Food and Environment 8, 3, 39-46.

Gabor, G. S. (2005): Co-operative Identity-A Theoretical Concept for Dynamic Analysis of Practical Cooperation: The Dutch Case. Paper prepared for presentation at the XIth International Congress of the EAAE (European Association of Agricultural Economists), 'The Future of Rural Europe in the Global Agri-Food System', Copenhagen, Denmark: August 24-27, 2005.

Gbigbi, T. M., Achoja, F. O., Temile, S. O. (2019): Cooperative Funding as Driver of Aquaculture Development: Evidence from Nigeria, European Journal of Social Sciences. 58, 2, 124-133.

Hartley, C. W. (2003): The improvement of natural palm grooves. Journal of Agricultural Economics Research 1, 2, 38-41.

Ibitoye, S. J. (2012): Survey of the performance of agricultural cooperative societies in Kogi State, Nigeria. European Scientific Journal. 8, 28, 98-114.

ICA (2005): http://www.ica.coop/ (accessed November, 2016).

ICA Housing Co-operatives in USA (2007): Available at: http://www.ica.coop/a1-housing/attachments/ Housing\%20coopratives\%20in\%20USA\%20\%FINAL. pdf. 
Kudi, T. M., Bako, F .P., Atala, T. K (2008): Economics of fish production in Kaduna State. Journal of Agricultural and Biological Science. 3, 5-6, 17-21.

Olaoye, O. J., Adelaja, A. B., Ashley-Dejo, S. S., Omoyinmi, G. A. K., Idowu, A. A., Odebiyi, C. B. (2012): Impact of Nigerian Agricultural Cooperative and Rural Growth Bank Loan (NACRDB) on Fish Farming Enterprises in Ogun State, Nigeria Nigerian Journal of Fisheries. 9, 1, 468-476.

Nweke, F. I., Akerhe, J. A. (2005): Determinants of adoption of new technologies among smallholders and implications for administration of transfer programme. A case study of rice production in the plateau State of Nigeria. Agricultural Administration, 12, 1, 78-82.
Sharma, N., Simkhada, N. R., Shrestha, R. (2005): Impact assessment of SACCOSs in Nepal's hill district. Findings of an action research Kathmandu: centre for microfinance (PVT) Itd.

The World Fish Center (2009): The World Fish Center, Penang. 57. 